CZASOPISMO INŻYNIERII LĄDOWEJ, ŚRODOWISKA I ARCHITEKTURY

JOURNAL OF CIVIL ENGINEERING, ENVIRONMENT AND ARCHITECTURE

JCEEA, t. XXXIV, z. 64 (4/I/17), październik-grudzień 2017, s. 185-204, DOI:10.7862/rb.2017.205

Krzysztof ŚLEDZIEWSKI ${ }^{1}$

\title{
FATIGUE ASSESSMENT OF BRIDGE STRUCTURES ACCORDING TO EUROCODES
}

\begin{abstract}
Fatigue is one of the main causes of damage in many structures. The process of fatigue damage is rather complicated and the design of structures with reference to fatigue requires a good knowledge in several fields including structural analysis, material mechanics and modeling of loads and load effects on structures. Therefore standards and recommendations related to fatigue design and analysis are often needed to assist the structural engineer in his design work. This applies both to the design of new bridges and the analysis of the remaining service life of existing bridges. General rules for determining all effects on bridges are specified in EN 1990 and Appendix A2. Verification if there is no structural damage due to fatigue should be performed in accordance with the scheme of EN, include the scope of the Ultimate Limit Stage (ULS) verifications. For the reason, that fatigue failure does not occur as a result of the load of a fixed maximum value but as a result of repetition of imposing load on an average level of internal forces, the effect of fatigue depends strongly on the properties of construction materials - steel and concrete. Thus, the effect, in the form of fatigue may be quite different in the case of steel bridges, concrete bridges or even a composite steel-concrete bridges. Therefore, the rules for determining the fatigue load are not specified in the overall standard, but are moved to detailed design standards: EN 1992 to EN 1999. Because of the high complexity of the fatigue verification, in the work the general fatigue calculation rules are presented.
\end{abstract}

Keywords: damage, standards, design, verification, bridges

\section{Introduction}

The key issue for the assessment and forecasting of bridge endurance is the so-called bridge fatigue. The general rules for determining actions on bridges are specified in EN 1990: Basis of structural design and Appendix A1 [1]. The verification whether a structure will fail due to fatigue in accordance with EN standards falls within the scope of the ultimate limit strengths (ULT). In general, the load combinations that should be taken into account when verifying the ultimate limit state are provided by EN 1990, with the exception of load combinations that should be taken into account during the calculation of fatigue (FAT). Be-

\footnotetext{
${ }^{1}$ Krzysztof Śledziewski, Lublin University of Technology, Department of Roads and Bridges, ul. Nadbystrzycka 40, 20-618 Lublin; tel. 815384379; k.sledziewski@pollub.pl
} 
cause a fatigue failure does not occur as a result of an action of the load with a specified maximum value but as a result of the repeatability of a load added to some average level of internal forces, the effect of a fatigue failure depends largely on the properties of the construction materials used to build the structure. At the same load spectrum, the form of the fatigue failure may be quite different for concrete, steel and composite bridges. Therefore, the rules for determining fatigue loads have not been specified in the general EN 1990 standard but in the specific design standards: from EN 1992 to EN 1999.

All the standards for calculating the fatigue resistance of bridges adopt the Palmgren-Miner damage summation rule as the basis [2], [3]. This method requires the determination of a fatigue action on the basis of the measurements of the values and structure of the loading (the determination of the so-called load spectrum). In the absence of such data, it is recommended to use the so-called equivalent stress (meaning an equivalent range of stress variations) while verifying the fatigue resistance. This range is determined using the appropriate fatigue load model provided in EN 1991-2. The application of the appropriate model depends on the type of the structure.

In steel structures according to [4], the fatigue assessment should be carried out for all parts of the bridge if the construction of details does not comply with the standard requirements for permanent structures determined on the basis of tests.

\section{Fatigue load models}

\subsection{Road bridges}

The load models included in fatigue calculations are provided by EN 1991-2 standard. In the case of the structures they do not apply to, it is recommended to determine the fatigue actions on the basis of measurements or equivalent studies of expected spectra of variable actions on the structure.

The fatigue load models recommended in EN 1991-2 for road bridges are based on reference influence surfaces for different types of bridge structures, i.e. simply supported and continuous bridges for span length between $3 \mathrm{~m}$ and $200 \mathrm{~m}$ [5]. These load models can be divided in two main groups depending on the required fatigue life. The first group is used to verify infinite fatigue life. This group contains of FLM 1 and FLM 2. The second group of the fatigue load models is aimed for performing fatigue assessing for given fatigue design life using the damage accumulation method based on Palmgren-Miner rule or the damage equivalent concept, also called simplified $\lambda$-coefficient method. In this group, FLM 3 is applied when performing the damage equivalent concept and FLM 4 when performing the cumulative damage concept. The grouping of the fatigue load models for road bridges are compiled in Fig. 1 below. 


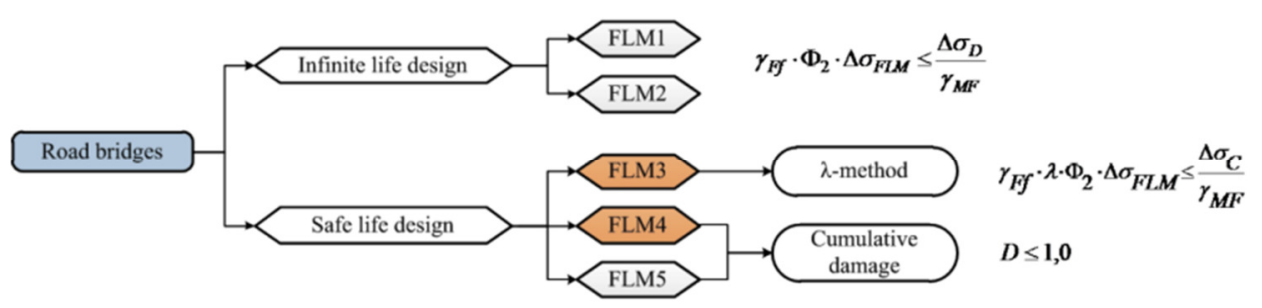

Fig. 1. Fatigue load models for road bridges, acc. to [6]

Rys. 1. Modele obciążeń zmęczeniowych, wg [6]

FLM 1 (similar to LM1) takes the form of the characteristic Load Model 1 with the axis load values equal to $0.7 \cdot Q_{\mathrm{ik}}$ and the evenly distributed load values equal to $0.3 \cdot q_{\mathrm{ik}}$ and $0.3 \cdot q_{\mathrm{rk}}$ (unless specified otherwise).

FLM 2 (a set of "frequent" lorries) consists of a set of idealised lorries referred to as "frequent" lorries. Each "frequent lorry" is defined with a number of axles and their spacing, the frequent axle load, the wheel contact area and the crosswise distance between the wheels.

FLM 3 (single vehicle model) consists of four axles, each having two identical wheels - Fig. 2. The load on each axle is equal to $120 \mathrm{kN}$ and the contact area of each wheel is a square with the side of $0.40 \mathrm{~m}$.

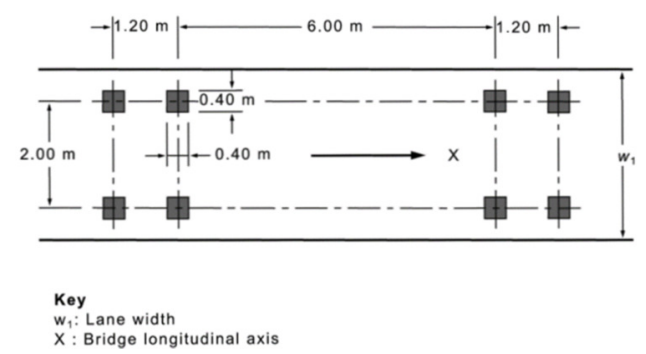

Fig. 2. Fatigue Load Model 3, acc. to [5]

Rys. 2. Model obciążenia zmęczeniowego 3, wg [5]

FLM 4 (a set of standard lorries) consists of sets of standard lorries which jointly produce effects that are equivalent to those that occur in a typical traffic on European roads. It is recommended to consider the set of lorries that is appropriate for the mixed traffic expected on the route;

FLM 5 (based on road traffic measurement data) involves the direct application of measured traffic data supplemented - if needed - with relevant statistical or projected extrapolations.

The fatigue load models 1, 2 and 3 are recommended for use in determining the maximum and minimum stress in spots susceptible to fatigue. The models 4 and 5 are used in determining the stress range spectra caused by passing lorries 
with the characteristics described in these models. In addition, the models 1 and 2 are mainly used to verify the fatigue resistance of the structures for which the so-called cut-off limit was determined. In the case of such structures, we can determine the direct stress range $(\Delta \sigma)$, the non-exceedance of which does not result in a fatigue failure for a specific type of structure or connection, regardless of the number of variations in the value.

The models 1 and 2 are therefore applicable when verifying steel structures to determine the structure life as a result of the appearance of a fatigue damage. In the case of concrete structures, such an approach has not been defined. Consequently, they do not have a specified acceptable stress range whose nonexceedance guarantees a certain fatigue life of the structure, regardless of the number of stress cycles.

The models 3, 4 and 5 are applicable to the assessment of fatigue resistance of a structure by reference to the fatigue strength curves defined in EN-1992 to 1999. The fatigue load model 3 is used in the verification of fatigue of concrete bridges on the basis of a comparison of equivalent stresses.

The most universal fatigue model is the load model 5 , which uses the actual traffic data. In practice, though, it can be used only in for the verification of the resistance of existing bridges or when we have a detailed study of the structure of traffic at the location of the planned civil engineering structure. This can be the case e.g. in a situation where we are planning to replace an existing civil structure. Additionally, the standard (EN 1991-2) recommends to define the category of the traffic on the bridge for fatigue calculations on the basis of at least:

- the number of slow traffic lanes (i.e. the lanes used mainly by lorries),

- the number $N_{\mathrm{obs}}$ of lorries (with a maximum overall weight greater than $100 \mathrm{kN}$ ), measured or estimated annually for one slow traffic lane.

The assessment of the suitability of the fatigue load models for the analysis of a variety of bridge structures depending on the method used to calculate fatigue is shown in Table 1.

Table 1. The use of fatigue load models, based on [5]

Tabela 1. Zastosowanie modeli obciążeń zmęczeniowych, na podstawie [5]

\begin{tabular}{|c|c|c|c|c|c|}
\hline \multirow{2}{*}{$\begin{array}{c}\text { Structure } \\
\text { type }\end{array}$} & \multicolumn{3}{|c|}{$\begin{array}{l}\text { Determination of maximum } \\
\text { and minimum stress }\end{array}$} & \multicolumn{2}{|c|}{$\begin{array}{l}\text { Determination of stress } \\
\text { range spectrum }\end{array}$} \\
\hline & Model 1 & Model 2 & Model 3 & Model 4 & Model 5 \\
\hline concrete & & & $\mathrm{X}$ & $\mathrm{X}$ & $\mathrm{x}$ \\
\hline steel & $x^{*}$ & $x^{*}$ & $\mathrm{x}$ & $\mathrm{x}$ & $\mathrm{x}$ \\
\hline composite & & & $\mathrm{x}$ & $\mathrm{x}$ & $\mathrm{x}$ \\
\hline
\end{tabular}

The internal forces required in the fatigue analysis of any bridge structure can be calculated on the basis of a global elastic analysis. For concrete struc- 
tures, the verification of structure fatigue is performed separately for concrete and steel. The concrete fatigue verifications use a basic combination of noncyclic actions (defined similarly to the frequent combination in (SLS) serviceability limit states). In steel verifications (for both reinforcing and pre-stressing steel), though, the cyclic action is considered together with the adverse basic combination, the so-called basic combination with cyclic action $Q_{\text {fat }}$ [7]. In fatigue calculations for steel structures, stress ranges are determined based on frequent loads [8]. In turn, in composite structures, the internal forces for fatigue analysis should be determined in the same way as for concrete structures according to the load combinations specified in [7].

The fatigue resistance based on the simplified method can be calculated using the fatigue load model 3 , while the verification of the reinforcement and tendons must be carried out on the basis of the multiplier load model proposed in the annexe to EN 1992-2.

\subsection{Railway bridges}

The load models for the fatigue verification of railway bridges in Eurocode can be categorised into two main groups depending on the fatigue assessment methods (Fig. 3). The first group is meant to be used for fatigue verification using the simplified $\lambda$-coefficient method. This group contains fatigue load model 71 (FLM 71), fatigue load model SW/0 (FLM SW/0) and fatigue load model SW/0 (FLM SW/2).

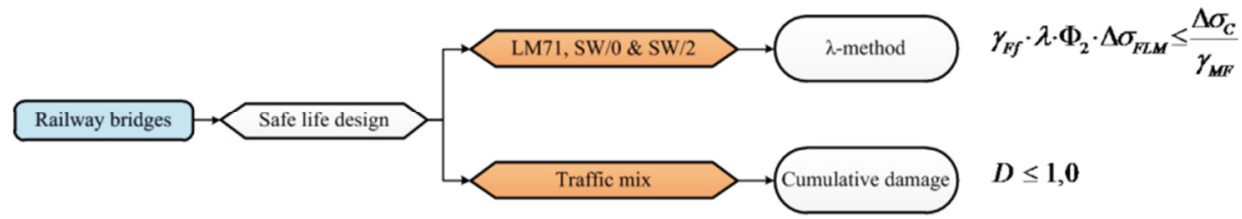

Fig. 3. Fatigue design procedure of railway bridges, acc. to [6]

Rys. 3. Procedura projektowania zmęczeniowego mostów kolejowych, wg [6]

The second group of load models is meant to be used when the fatigue verification is to be performed using the damage accumulation concept based on Palmgren-Miner rule. This group contains different traffic mixes: "normal", "light" or "with $250 \mathrm{kN}$ pressure on each axle". If the traffic composition does not represent the actual traffic, it is recommended to use a specified alternative composition. This can be specified in the individual technical documentation.

A fatigue analysis should take into account the vertical actions of railway traffic along with dynamic effects and centrifugal forces. The lateral impacts and longitudinal traffic action may be ignored.

If the dynamic effects in the structure where the dynamic analysis is required are estimated to be excessive, some additional requirements for the assessment of bridge fatigue should be considered. 
Detailed information on the trains and traffic composition as well as dynamic excesses taken into account in a railway bridge fatigue analysis are given in (normative) Annexe D to EN 1991-2. This annexe also specifies 12 types of trains for fatigue which should be used in a fatigue analysis, depending on what traffic composition is expected for a given civil structure - Fig. 4.

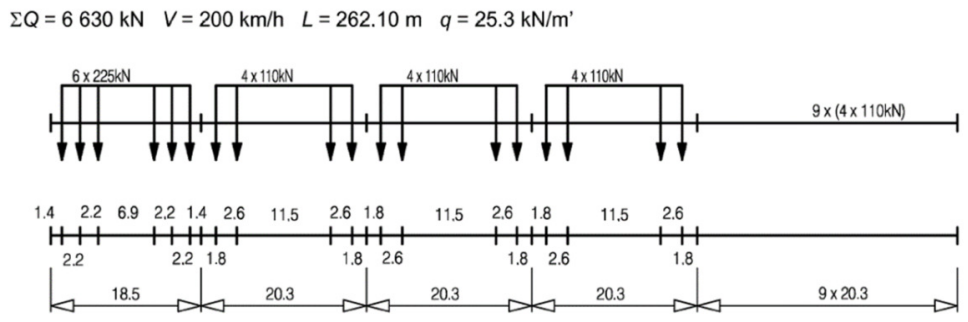

Fig. 4. An example of a train type for fatigue in normal and light traffic compositions - A type 1 railway engine pulling a passenger train, acc. to [5]

Rys. 4. Przykładowy typ pociągu zmęczeniowego w kompozycji ruchu normalnego i lekkiego - Typ 1 Lokomotywa ciągnąca pociąg pasażerski, wg [5]

We use the load model 71 while calculating the fatigue of reinforcing and pre-stressing steel for concrete bridges based on the comparison of equivalent stress. Where it is required, one should apply the model SW/0 (for continuous bridges), omitting the factor $\alpha$. When verifying the fatigue of pre-stressed concrete, we take into account the characteristic combination of actions with the inclusion of the model 71 (with the appropriate factor $\alpha$ ) with a dynamic factor.

In fatigue verification using the equivalent stress method for both steel and composite bridges, we use the characteristics model 71 values, including the dynamic factor.

\section{Fatigue design methods}

Load effects generated by traffic loads on bridges are generally very complex. Not only are the stress ranges generated by these loads of variable amplitudes, but also other parameters that might affect the fatigue performance of bridge details such as the mean stress values and the sequence of loading cycles are rather stochastic.

In order to treat such complex loading situations there is a need to represent the fatigue load effects caused by the "actual" variable amplitude loading in term of equivalent constant amplitude loading. In other words, a complex loading situation should be represented as one or more equivalent constant amplitude loads, so that the latter will cause equivalent fatigue damage as the real loading history. Two steps are needed. First step is transformation of the variable amplitude loading into a representative constant amplitude loading, this is usually 
done by some kind of cyclic counting method and the second step is using the new set of representative constant amplitude loading to perform the fatigue design or analysis, this is done either directly, by applying the Palmgren-Miner damage accumulation rule, or by using the equivalent stress range concept.

The rules concerned with the fatigue design of bridges in Eurocode allow for the application of any of these two methods. The simplified $\lambda$-method in Eurocode is an adaption of the general equivalent stress range concept corrected by various $\lambda$-factors, while a direct application of the Palmgren-Miner rule can alternatively be used for both railway and road bridges.

The principles of the Palmgren-Miner damage rule and the concept of equivalent stress range are however introduced below.

\subsection{Damage Accumulation Method}

Bridge dimensioning standards [4], [8], [9], as recommend the damage summation method as the basic method for calculating fatigue resistance. The most important assumptions of this method include the following [10]:

- each sinusoidal damage group is involved in the damage of the component in proportion to the $n_{i} / \mathrm{N}_{\mathrm{i}}$ ratio,

- the damage is not dependent on the location of the group throughout the load spectrum,

- the total damage is equal to the sum of the damage caused by each load group separately.

In order to ensure the protection against fatigue failure, the following condition should be true:

$$
D_{\mathrm{d}} \leq 1,
$$

where the measure of the component damage is the ratio between the number of purely sinusoidal load cycles $(n)$ to the achieved service life with the same loading parameters $(N)$ :

$$
D_{\mathrm{d}}=\frac{n}{N}
$$

The damage $D_{\mathrm{d}}$ during the design life should be determined from:

$$
D_{\mathrm{d}}=\sum_{\mathrm{i}}^{\mathrm{n}} \frac{n_{\mathrm{Ei}}}{N_{\mathrm{Ri}}}
$$

where: $n_{\mathrm{Ei}}-$ is the total number of cycles with the stress range $\gamma_{\mathrm{Ff}} \Delta \sigma_{\mathrm{i}}$ (in band $\mathrm{i}$ in the factored spectrum),

$N_{\mathrm{Ri}}$ - is the number of load cycles (Fig. 5) which would lead to the failure for the action of the load with the range of $\gamma_{\mathrm{FF}} \Delta \sigma_{\mathrm{i}}$, obtained from the factored curve $\Delta \sigma_{\mathrm{c}} / \gamma_{\mathrm{Mf}}-N_{\mathrm{R}}$, 
$\gamma_{\mathrm{Ff}}-$ is the partial factor for fatigue actions,

$\gamma_{M}-$ is the partial factor for fatigue strengths,

$N_{\mathrm{R}}$ - is the design life time related to the constant amplitude stress range.

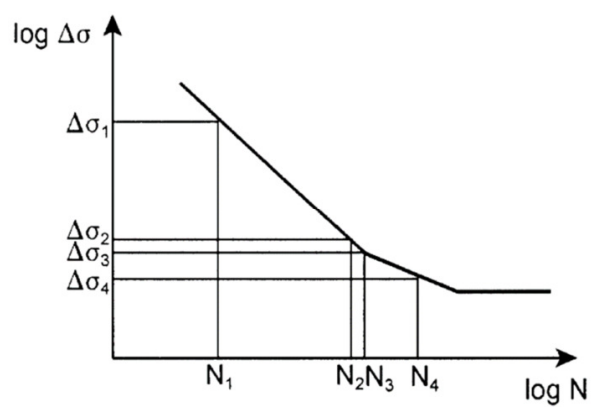

Fig. 5. Cycles to failure, acc. to [8]

Rys. 5. Liczba cykli do zniszczenia, wg [8]

In order to obtain the endurance value $N_{\mathrm{Ri}}$ for each band in the spectrum, the applied stress ranges are multiplied by $\gamma_{\mathrm{Ff}}$, and the fatigue strength values are divided by the partial factor $\gamma_{\mathrm{Mf}}$. Using the method of damage summation, we must know the load spectrum of the structure. Therefore, this method is suitable for the estimation of the endurance of a structure already in use whose stress history is known. For a newly-designed structure, one should predict the method of loading the structure: the amount of the expected loading, including its structure throughout its service life.

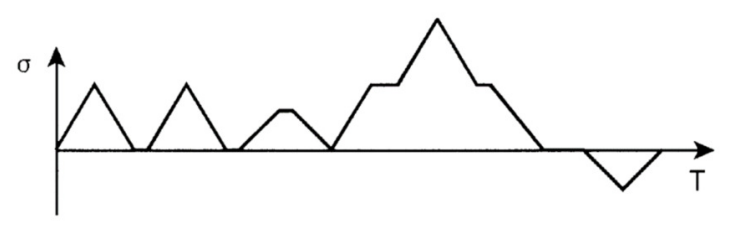

Fig. 6. Stress history at detail, acc. to [8]

Rys. 6. Historia naprężeń w elemencie, wg [8]

The stress history is determined on the basis of loading events associated with the structural detail under consideration, taking into account the type and shape of the relevant influence lines and the effects of dynamic magnification of the structural response (Fig. 6). The stress history may also be determined from measurements carried out on similar structures or from dynamic calculations of the structural response. 


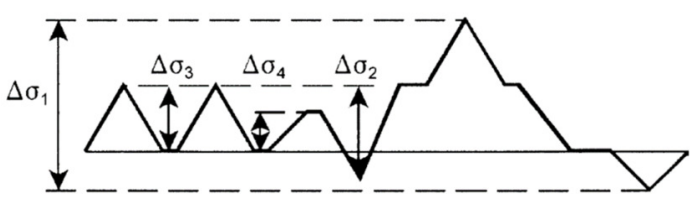

Fig. 7. Cycle counting (e.g. reservoir method), acc. to [8]

Rys. 7. Zliczanie cykli (np. metodą zbiornikową), wg [8]

Counting the cycles can be evaluated in one of two methods (Fig. 7). For short stress histories, where a single loading event recurs multiple times, it is recommended to use the "reservoir method". Where the stress history is long and complex (e.g. obtained from tensometric measurements on the actual structure) the rainflow method is recommended.

\subsection{Equivalent Stress Method}

The difficulties in determining the load spectrum (its variations over the upcoming several years) in the design phase of the new civil structure force a fatigue resistance verification based on the equivalent stress method.

This method is based on the concept of the equivalent stress range. The equivalent constant amplitude stress range is the range of stress variations that corresponds to the same fatigue life as in the case of design spectrum based on the damage summation according to the Palmgren-Miner rule. The equivalent stress is such stress $\sigma_{\mathrm{c}}$ that will result in the failure of the component after $N_{\mathrm{F}}$ multi-level stress cycles. The equivalent stress will cause the same damage to the specimen as a complex load spectrum with the same total number of cycles.

Based on the equivalence of parameters $D_{\mathrm{d}}$, the design stress range spectrum can be converted into any equivalent design stress range spectrum. This can be e.g. a constant amplitude stress range spectrum corresponding to the equivalent fatigue load $Q_{\mathrm{e}}$ related to the number of cycles $n_{\max }=\Sigma n_{\mathrm{i}}$ or the fatigue load $Q_{\mathrm{E}, 2}$ related to the number of cycles of $N_{\mathrm{c}}=2 \cdot 10^{6}$.

The fatigue resistance condition in the method of equivalent stress is described by the following relation:

$$
\gamma_{\mathrm{Ff}} \cdot \Delta \sigma_{\mathrm{E}} \leq \frac{\Delta \sigma_{\mathrm{c}}}{\gamma_{\mathrm{Mf}}}
$$

where: $\Delta \sigma_{\mathrm{E}}-$ is the stress range adequate to the calculated component and related to a specific number of load cycles (two million cycles) calculated in accordance with the relevant structure dimensioning standards,

$\Delta \sigma_{\mathrm{c}}$ - is the reference value of the fatigue strength given in the appropriate dimensioning standard. 
Except for the fatigue verification for the pre-stressed concrete, all bridge dimensioning standards provide the same condition for the verification of fatigue resistance, using the equivalent stress method. One can observe some exceptions in the recommended values of partial safety factors and the recommended load models used to determine the equivalent stress. In addition, the individual variables are designated differently.

The value of the partial action factor in accordance with EN 1992-2, 1993-2 and 1994-2 should be taken as equal to $\gamma_{\mathrm{Ff}}=1.0$. However, the way of designating this factor in the above standards is different. It is designated as $\gamma_{\mathrm{F} \text {,fat i }}$ in standard 1992-2 and as $\gamma_{\mathrm{Ff}}$ in standards 1993-2 and 1994-2.

In turn, in the case of a partial fatigue strength safety factor $\gamma_{\mathrm{MF}}$, both its value and designation vary depending on the standard. Therefore, in standard EN 1992-2, the factor for the reinforcing or pre-stressing steel has a designation of $\gamma_{\text {s,fat }}$. Its value for permanent and transitional situations should be taken as equal to 1.15 , or 1.0 in exceptional situations. In contrast, in the standard for steel bridges EN 1993-2, this factor has the designation of $\gamma_{\mathrm{MF}}$ and its recommended values depend on the failure consequences and assessment method (Table 2).

Table 2. The recommended values for the partial safety factor for fatigue strength of steel structures, based on [8]

Tabela 2. Zalecane wartości częściowego współczynnika bezpieczeństwa wytrzymałości zmęczeniowej konstrukcji stalowych, na podstawie [8]

\begin{tabular}{|c|c|c|}
\hline \multirow{2}{*}{ Assessment method } & \multicolumn{2}{|c|}{ Failure consequence } \\
\cline { 2 - 3 } & Low & Large \\
\hline Safe line & 1.15 & 1.35 \\
\hline Damage tolerant & 1.00 & 1.15 \\
\hline
\end{tabular}

The safe life method should provide an acceptable level of reliability that a structure will perform satisfactorily for its design life without the need for regular in-service inspection for fatigue damage. The safe life method should be applied in cases where a local formation of cracks in one part could rapidly lead to failure of a component or structure.

The damage tolerant method provides an acceptable reliability that a structure will perform satisfactorily for its design life, provided that a prescribed inspection and maintenance regime for detecting and correcting fatigue damage is implemented throughout the design life of the structure. The damage tolerant method may be applied when a load redistribution between components of structural elements can occur in the event of fatigue damage occurrence.

The process of the design of new structures usually uses the safe life method, which is the most conservative but ensures the maximum reliability of the structure. The damage tolerant method is applied only in the case the fatigue life determined for the design spectrum calculated by the safe life method is shorter than the designed service life of the structure. 
In the case of composite bridges [11], the factor $\gamma_{\mathrm{MF}}$ takes the same values for a steel part as for steel structures, for a concrete part - as for concrete, and for composite connectors - the value of 1.0. The value of the partial safety factor for pins may also have a different value if it is provided in the national annexe. The standard does not have any information on the factor values for other types of connectors. However, by analysing the provisions for composite structures, it seems that one may take the same values for them as for connectors made of pins.

\subsection{The $\lambda$-Coefficient Method}

The $\lambda$-coefficient method is a conventional simplified fatigue assessment method, which is based on comparing an equivalent stress range with the studied detail category. The basic idea with this method is that the fatigue damage caused by the stress range spectrum is associated with an equivalent stress range $\Delta \sigma_{\mathrm{E}}$ or an equivalent stress range at 2 million stress cycles $\Delta \sigma_{\mathrm{E}, 2}$. The method is derived originally for railway bridges, but applies also for road bridges. The purpose of this method is to convert fatigue verifications using $\lambda$-coefficients into a conventional fatigue resistance control, i.e. stress range check.

The conventional fatigue resistance control is on the basis of conditioning a lower or equal maximum stress range to the detail capacity stress range. The maximum stress range is the stress obtained from the fatigue load models which were originally derived to be used with this method. The fatigue verification is expressed as:

$$
\lambda_{F f} \cdot \Phi_{2} \cdot \Delta \sigma_{F L M} \leq \frac{\Delta \sigma_{C}}{\lambda_{\max }},
$$

where: $\lambda-$ is the fatigue damage equivalent factor related to $2 \cdot 10^{6}$ cycles,

$\Phi_{2} \quad$ - is the dynamic factor,

$\Delta \sigma_{\mathrm{FLM}}$ - is the stress range due to the fatigue load model,

$\Delta \sigma_{\mathrm{C}}-$ is the reference stress range value of the fatigue strength.

The correction factor, which expresses the influence of span, annual traffic volume, design life, the multiplicity of bands, traffic type and surface roughness, can be calculated from:

$$
\lambda=\lambda_{1} \cdot \lambda_{2} \cdot \lambda_{3} \cdot \lambda_{4} \leq \lambda_{\max },
$$

where: $\lambda_{1} \quad-$ is the factor dependent on the type of the component (e.g. a continuous beam) and taking into account the effect of the damage caused by traffic, depending on the influence line surface length,

$\lambda_{2}-$ is the factor taking into account the volume of traffic; determines the influence of the annual volume and type of traffic,

$\lambda_{3}-$ is the factor taking into account the design service life of the bridge, 
$\lambda_{4}-$ is the factor of the traffic on other lanes,

$\lambda_{\max }$ - is the maximum value of $\lambda$ taking into account the fatigue limit, depending on the type of load, the length of span or section where the resistance is being verified.

\section{Fatigue assessment procedure}

An example of a fatigue assessment procedure is shown for metal platforms (steel and aluminium) using the safe life method [12]. The general procedure consists of the following main stages:

- the identification of spots in the structure that are susceptible to fatigue (the so-called notches),

- the determination of loading events, i.e. a defined loading sequence applied to the structure and giving rise to a stress history, which is normally repeated a defined number of times in the life of the structure.

- the analysis of the stress history, i.e. a record or a calculation of the stress variation in spots susceptible to fatigue during a loading event,

- the determination of the stress range spectra using one of the methods of counting cycles and the determination of the design spectrum,

- the selection of the appropriate fatigue category (i.e. fatigue strength) for spots susceptible to fatigue and the determination of the design life for the individual stress ranges from the design spectrum,

- the linear cumulative damage calculation based on the Palmgren-Miner rule

- the safe life calculation and the verification if it is longer than the planned service life of the structure.

If the fatigue assessment carried out according to this procedure gives a negative result, one of the following is possible:

- conducting a fatigue re-assessment using damage tolerant method, including the control procedures enforced by this method,

- a redesign of the structure or component in order to reduce the level of stress,

- a replacement of the detail (e.g. connection type) for a solution with a higher fatigue (strength) category.

It is recommended to carry out a fatigue verification for all the structures and components that are exposed to regular load cycles. It is not necessary to carry out a fatigue assessment, though, in the case of:

- the reinforcing and pre-stressing steel in the areas where only compressive stresses from the frequent combination of actions occur,

- foundations,

- retaining walls of road and rail embankments,

- the bridge abutments as well as pillars and columns that are not rigidly connected to the span structure (with the exception of the abutment plates with holes), 
- the steel railway bridge parts that are not sensitive to the wind load and are not overloaded by traffic,

- the external and unbonded tendons located in the area of the cross-section height of concrete bridges for pedestrians - unless the analysis concerns the structural components that are susceptible to the wind or pedestrian traffic,

- the bridges over waterways and underground vaulted and framing structures.

\section{Worked example - fatigue design of a railway bridge}

A verification of the fatigue life of a railway bridge is treated in this example [6]. The verification is made with reference to one select structural details for the sake of demonstration. The simplified $\lambda$-method is demonstrated.

\subsection{General description}

The railway bridge is a steel bridge with a single span of $20.0 \mathrm{~m}$. The crosssection of the bridge is composed of two steel girders with a common upper flange forming together an open hat-shaped profile. The cross-section dimensions are kept constant along the entire span (Fig. 8). The two steel girders are joined by U-shaped diaphragms at each $\mathrm{L} / 4$, which are bolted to welded vertical stiffeners.

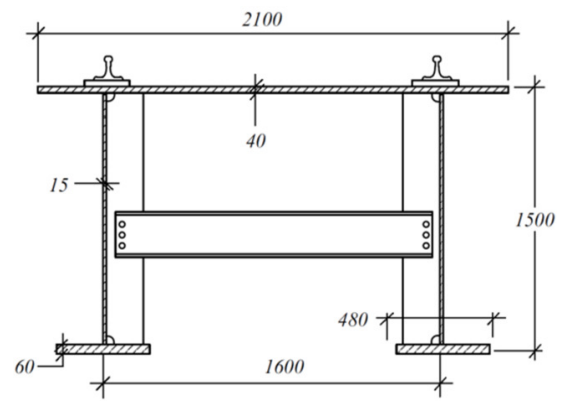

Fig. 8. Cross-section of the considered railway bridge, acc. to [6]

Rys. 8. Przekrój poprzeczny rozpatrywanego mostu kolejowego, wg [6]

Butt welds are used to connect the upper flange to the web as well as for the connection between the vertical stiffeners and the upper flanges. $5 \mathrm{~mm}$ fillet welds are used for the connections at the bottom side of the girders. The steel grade used for all load-carrying parts in the bridge is S355. Properties for the fatigue verification are listed in Table 3. 
Table 3. Cross-section constants used in fatigue verification, based on [6]

Tabela 3. Charakterystyki geometryczne przekroju wykorzystywane do oceny zmęczeniowej, na podstawie [6]

\begin{tabular}{|c|c|c|c|c|c|}
\hline $\boldsymbol{I}$ & $\boldsymbol{A}$ & $\boldsymbol{y}_{\mathbf{G C}}$ & $\boldsymbol{W}_{\text {top }}$ & $\boldsymbol{W}_{\text {bot }}$ & $\boldsymbol{S}_{\text {bot }}$ \\
\hline$\left[\mathrm{mm}^{\mathbf{4}}\right]$ & {$\left[\mathrm{mm}^{2}\right]$} & {$[\mathrm{mm}]$} & {$\left[\mathrm{mm}^{3}\right]$} & {$\left[\mathrm{mm}^{3}\right]$} & {$\left[\mathrm{mm}^{3}\right]$} \\
\hline $7.531 \cdot 10^{10}$ & $1.626 \cdot 10^{5}$ & 627 & $-1.202 \cdot 10^{8}$ & $8.623 \cdot 10^{7}$ & $5.031 \cdot 10^{7}$ \\
\hline
\end{tabular}

\section{Bridge specific traffic data}

The following bridge specific data has been adopted in this example:

- design life $=120$ years,

- the safe life assessment method should be used for bridges with high consequence of failure,

- partial factors for fatigue: $\gamma_{\mathrm{Ff}}=1.0(1993-2: 9.2)$, $\gamma_{\mathrm{Mf}}=1.35$ otherwise (1993-1-9, Table 3.1),

- rail traffic with $25 \mathrm{t}$ axels is used for fatigue verification (1993-2, 9.5.3),

- the traffic per year is specified to 25 million tons per track,

- carefully maintained track is assumed.

\subsection{Fatigue verification using the simplified $\lambda$-method}

For the sake of this example, the fatigue verification is made for the connection of the vertical stiffener to the lower flange of the main girders at midspan, i.e. $\mathrm{x}=10.0 \mathrm{~m}-$ Fig. 9 .

The fatigue strength curve for select detail is shown in Fig. 10.

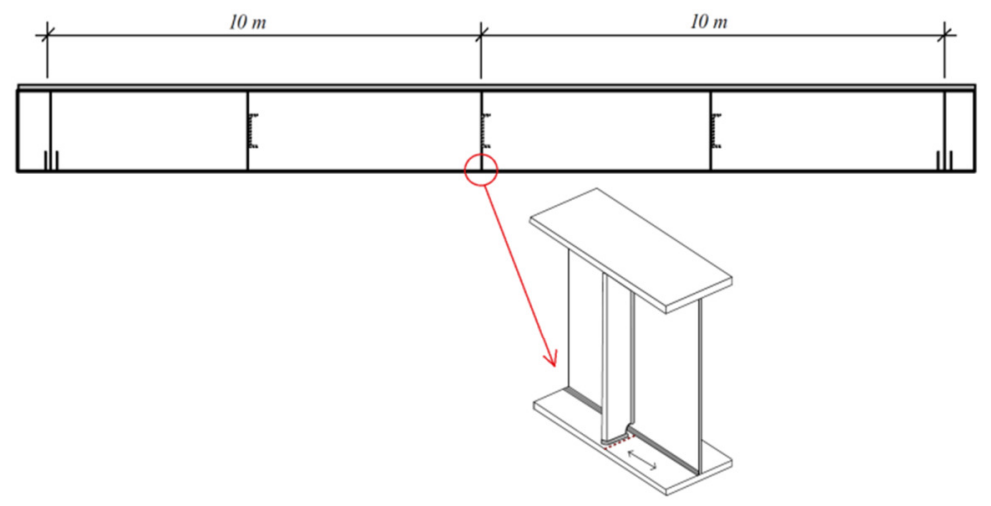

Fig. 9. The detail selected for fatigue verification, acc. to [6]

Rys. 9. Szczegół wybrany do oceny zmęczeniowej, wg [6] 


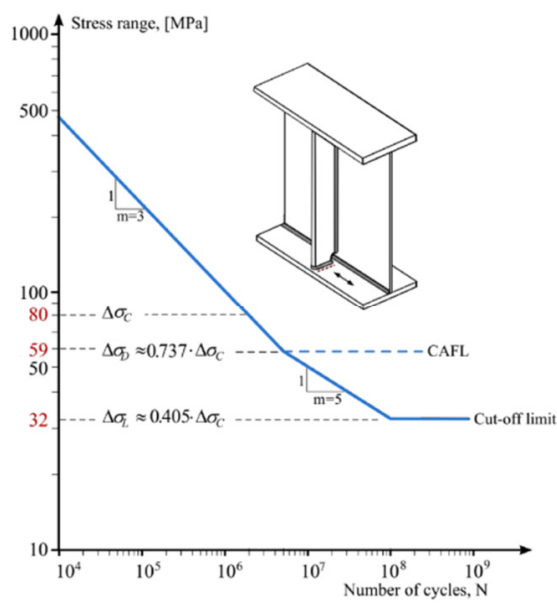

Fig. 10. Fatigue resistance data, acc. to [8]

Rys. 10. Dane odporności na zmęczenie, wg [8]

Detail Category 80 applies as given for Detail 7 in EN 1993-1-9, Table 8.4 assuming that the thickness of the vertical stiffener with the fillet welds on each side is less than $50 \mathrm{~mm}$. Thus:

$$
\begin{aligned}
\Delta \sigma_{C} & =80.0 \mathrm{MPa}, \\
\Delta \sigma_{D} & =59.0 \mathrm{MPa}, \\
\Delta \sigma_{L} & =32.0 \mathrm{MPa} .
\end{aligned}
$$

\section{Train load model and load effects}

The traffic load model for fatigue verification of railway bridges is LM71 (Fig. 11). Relevant load effects for fatigue verification of select detail are obtained by placing LM71 in the most unfavorable position.

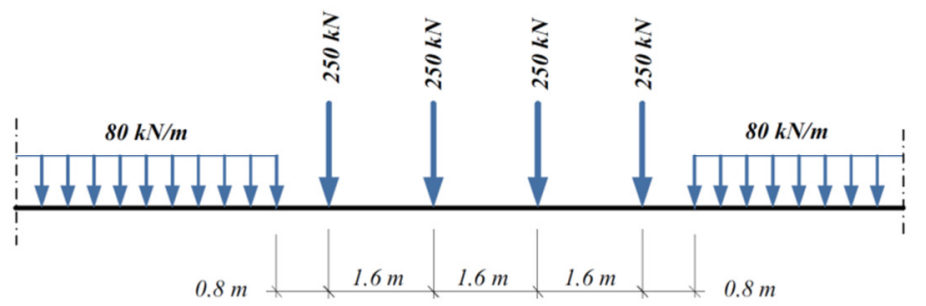

Fig. 11. Traffic load model LM71, acc. to [5]

Rys. 11. Model obciążenia ruchomego LM71, wg [5] 
Normally this is easily obtained from various computer programs. In this simple example, and for the sake of demonstration, hand calculations are used to obtain the stress ranges for fatigue verification. The results - in term of sectional forces - are given in Fig. 12.

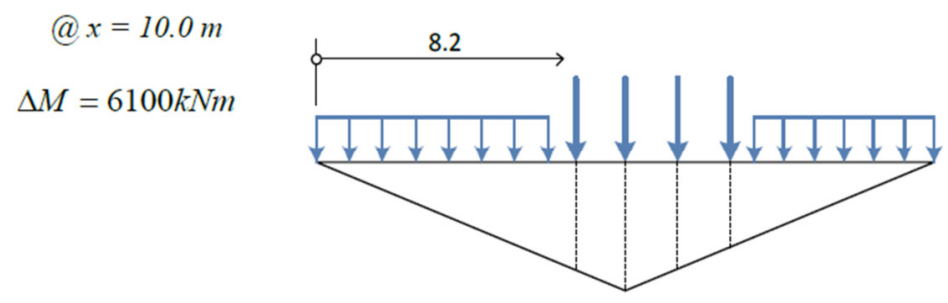

Fig. 12. Influence lines and load positions, acc. to [6]

Rys. 12. Linie wpływu i położenie obciążenia, wg [6]

In term of stresses at relevant check point, the load effects is:

$\Delta \sigma_{\mathrm{p}}=65.88 \mathrm{MPa}$ calculated at the top surface of the lower flange $@ \mathrm{x}=10 \mathrm{~m}$.

\section{Determination of the $\lambda$-factors}

For the structural steel detail in a steel railway bridge, the $\lambda$-factors can be obtained according to Eq. (6). The value of $\lambda_{\max }$ which takes into account the existence of the fatigue limit is defined in 9.5.3 (9) in EN 1993-2.

$\lambda_{\text {max }}=1.4$.

For determining $\lambda_{1}$, the critical length of the influence line needs to be determined. Section 9.5.3 (4) in EN 1993-2 should be applied. For a simplysupported bridge, the critical length of the influence line is equal to the span length, for both moment and shear action at midspan and near the supports.

For the simply-supported bridge with $\mathrm{L}=20.0 \mathrm{~m}$ and adopting "Rail traffic with 25 t axles" (EN 1993-2, 9.5.3 (3)):

$$
\lambda_{1}=0.68 \text {. }
$$

The traffic per year was specified to 25 million tons per track, which gives (EN 1993-2, 9.5.3 (5)]:

$$
\lambda_{2}=1.0 \text {. }
$$

Adopting a design life of 120 years (EN 1993-2, 9.5.3 (6)):

$$
\lambda_{3}=1.04 \text {. }
$$

With one track in the bridge, thus (EN 1993-2, 9.5.3 (7)):

$$
\lambda_{4}=1.0 \text {. }
$$


Finally:

$$
\lambda=0.68 \cdot 1.0 \cdot 1.04 \cdot 1.0=0.707 \leq \lambda_{\text {max }}=1.4 .
$$

For railway bridges a dynamic amplification factor should be included in the fatigue verification (EN 1991-2, 6.4.5.2 and D.2). For a carefully maintained track:

$$
\Phi_{2}=\frac{1.44}{\sqrt{L_{\phi}}-0.2}+0.82=1.157 \text { and } 1.0 \leq \Phi_{2} \leq 1.67 .
$$

where $L_{\Phi}$ is the determinant length of the bridge, which for the simply-supported bridge at hand is equal to the theoretical bridge span, $L$ (EN 1991-2, Table 6.2).

\section{Fatigue verification}

The fatigue verification can now be performed by comparing the equivalent stress range at 2 million cycles $\left(\Delta \sigma_{\mathrm{E}, 2}\right.$ or $\left.\Delta \tau_{\mathrm{E}, 2}\right)$ with the fatigue strength of each detail accounting for relevant partial factor for fatigue resistance $\left(\gamma_{\mathrm{Mf}}\right)$. In addition to the fatigue check in this format, a damage accumulation factor can also be derived for example from A.6 in EN 1993-1-9. The damage factor can be expressed as:

$$
D_{e q}=\left(\frac{\gamma_{M f} \cdot \gamma_{F f} \cdot \Delta \sigma_{E, 2}}{\Delta \sigma_{C}}\right)^{3}
$$

Therefore:

$$
\Delta \sigma_{p}=65.88 \mathrm{MPa} .
$$

and

$$
\Delta \sigma_{E, 2}=\lambda \cdot \Phi_{2} \cdot \Delta \sigma_{p}=0.707 \cdot 1.157 \cdot 65.88=53.90 \mathrm{MPa} .
$$

The fatigue verification reads:

$$
\frac{\gamma_{\mathrm{Ff}} \cdot \Delta \sigma_{\mathrm{E}, 2} \cdot \gamma_{\mathrm{Mf}}}{\Delta \sigma_{\mathrm{c}}}=\frac{1.35 \cdot 53.90 \cdot 1.0}{80}=0.91 \leq 1.0 .
$$

In term of equivalent damage, the result is:

$$
D_{e q}=\left(\frac{1.0 \cdot 1.35 \cdot 53.90}{80}\right)^{3}=0.753 \text {. }
$$

Figure 13 presents an overview of the application of the $\lambda$-coefficient method with the relevant parts of Eurocode involved in the fatigue verification with 
this method.

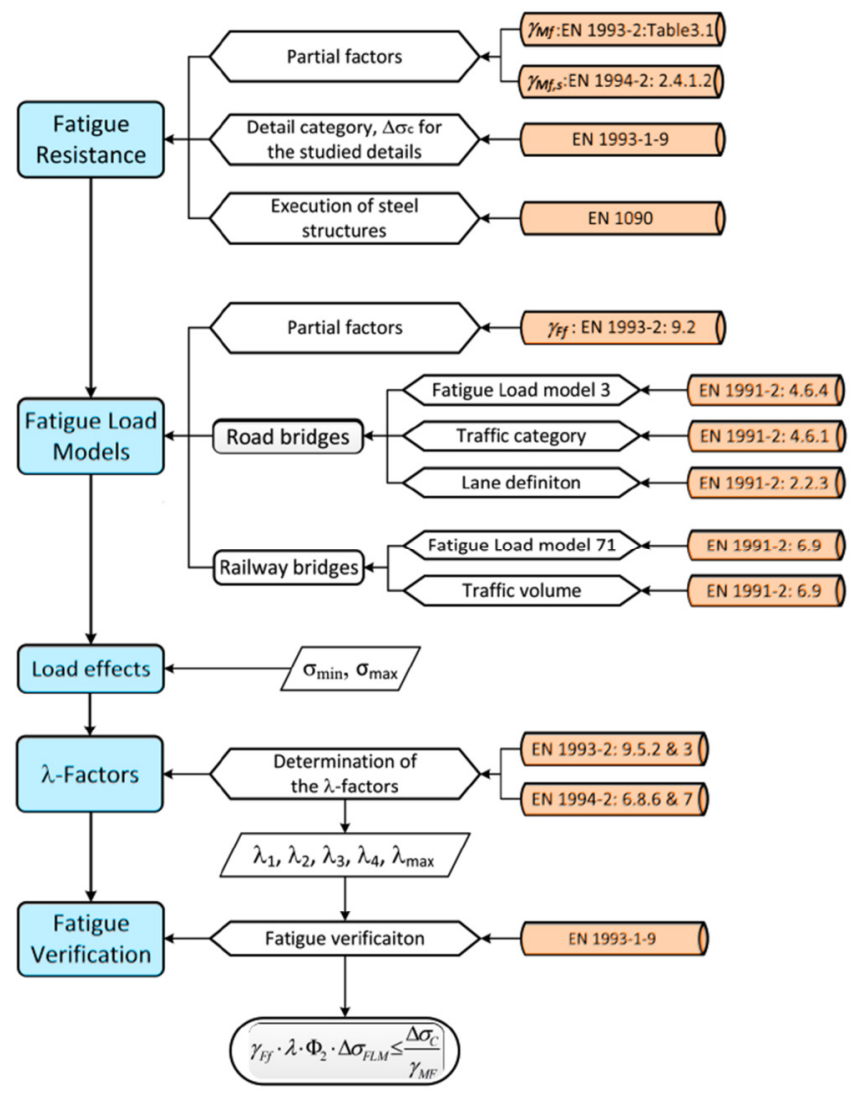

Fig. 13. The application next steps, acc. to [6]

Rys. 13. Kolejne kroki postępowania, wg [6]

\section{Conclusions}

The problem of the assessment of bridge endurance, both for road and railway bridges, has intensified significantly in recent years, and much worldwide research indicates that this trend will continue [12], [13]. Each of the types of bridges used nowadays has some sort of damage that causes a significant reduction in or limitation of its endurance, e.g. fatigue cracking. This damage causes a gradual loss of stiffness of the structural components, platforms etc. and a rapid degradation of the insulation and pavement, which leads to a reduction in the endurance of the entire civil structure. Therefore, the fatigue assessment is one of the most important design procedures, whose performance according to Euro codes is necessary both for newly designed bridges and in the assessment of the continued usability of the existing structures. 


\section{References}

[1] EN 1990, Eurocode 0: Basis of structural design, European Committee for Standardisation, Brussels 2004.

[2] Miner M.A.: Cumulative damage in fatigue, Journal Applied Mechanics, vol. 12(3), 1945, pp 159-164.

[3] Palmgren A.: Die Lebensdauer Von Kugellagern, Zeitschrift des Vereins Deutscher Ingenieure, vol. 68(14), 1924, pp 339-341.

[4] EN 1993-2, Eurocode 3: Design of steel structures, Part 2: Steel Bridges, European Committee for Standardisation, Brussels 2006.

[5] EN 1991-2, Eurocode 1: Actions on structures, Part 2: Traffic loads on Bridges, European Committee for Standardisation, Brussels 2003.

[6] Al-Emrani M., Aygül M.: Fatigue design of steel and composite bridges. Report 2014:10, Göteborg, Sweden 2014.

[7] EN 1992-1-1, Eurocode 2: Design of concrete structures, Part 1-1: General rules and rules for buildings, European Committee for Standardisation, Brussels 2004.

[8] EN 1993-1-9, Eurocode 3: Design of steel structures, Part 1-9: Fatigue, European Committee for Standardisation, Brussels 2005.

[9] EN 1992-2, Eurocode 2: Design of concrete structures, Part 2: Concrete bridges Design and detailing rules, European Committee for Standardisation, Brussels 2005.

[10] Czudek H., Pietraszek T.: The endurance of steel bridge structures with variable loads, WKŁ, Warszawa 1980.

[11]EN 1994-2, Eurocode 4: Design of composite steel and concrete structures, Part 2: General rules and rules for Bridges, European Committee for Standardisation, Brussels 2005.

[12] Siwowski T.: Fatigue assessment of existing riveted truss bridges: case study, Bull. Pol. Ac.: Tech., vol. 63(1), 2015, pp 125-133.

[13]Biondini F., Frangopol D.M. (eds): Bridge Maintenance, Safety, Management, Resilience and Sustainability, Proc. Of the Sixth International IABMAS Conference, Stresa, Lake Maggiore, Italy, 8-12 July 2013, CRC Press.

\section{OCENA TRWAŁOŚCI ZMĘCZENIOWEJ OBIEKTÓW MOSTOWYCH WEDŁUG EUROKODÓW}

\section{Streszczenie}

Zmęczenie jest jedną z głównych przyczyn uszkodzenia wielu konstrukcji. W związku z tym, procedura oceny trwałości zmęczeniowej jest jedną z najistotniejszych, w kompleksowej ocenie nośności i trwałości obiektu. Dotyczy to zarówno projektowania nowych mostów, jak i analizy pozostałego okresu eksploatacji istniejących mostów. Niezawodna ocena trwałości zmęczeniowej jest przede wszystkim decydująca przy szacowaniu pozostałej (resztkowej) przydatności eksploatacyjnej. Ogólne zasady ustalania oddziaływań działających na mosty określa norma EN 1990 wraz z Załącznikiem Al. Sprawdzenie, czy nie dojdzie do zniszczenia konstrukcji na skutek zmęczenia zgodnie z systemem norm EN, zaliczamy do zakresu stanów granicznych nośności (ULS). Z tego powodu, awarie zmęczeniowe nie występują w wyniku obciążenia o stałej wartości maksymalnej, ale w wyniku powtórzenia obciążenia na średnim poziomie sił wewnętrz- 
nych. Wpływ zmęczenia zależy w dużym stopniu od właściwości użytych materiałów konstrukcyjnych - stali i betonu. Końcowy efekt zmęczenia materiału (konstrukcji), może być zupełnie inny w przypadku mostów stalowych, mostów betonowych bądź mostów zespolonych typu stal-beton. Stąd też zasady określania obciążenia zmęczeniowego nie są określone w ogólnej normie, ale są przenoszone na szczegółowe normy projektowania od EN 1992 do EN 1999.

W niniejszej pracy przedstawiono ogólne reguły oceny trwałości zmęczeniowej mostów. Ponadto dokładnie omówiono obliczanie nośności zmęczeniowej zarówno metodą kumulacji uszkodzeń jak również metodą ekwiwalentnych naprężeń a także podano tok postępowania przy ocenie zmęczenia pomostów metalowych.

Słowa kluczowe: zniszczenie, normy, projektowanie, sprawdzenie, mosty

Przestano do redakcji: $12.05 .2017 \mathrm{r}$.

Przyjęto do druku: 15.12.2017 r. 